\title{
FAKTOR-FAKTOR YANG BERPENGARUH TERHADAP KEJADIAN DIARE PADA ANAK USIA 2-4 TAHUN DI WILAYAH KERJA PUSKESMAS BANDAR KECAMATAN BANDAR TAHUN 2015
}

\author{
Tiurlan Mariasima Doloksaribu, Marlina Sitanggang \\ Jurusan Keperawatan Poltekkes Medan
}

\begin{abstract}
Abstrak
Diare adalah penyakit yang ditandai dengan bertambahnya frekuensi buang air besar lebih dari biasanya (lazimnya frekuensi ini lebih dari $3 \mathrm{kali} / \mathrm{hari}$ ) disertai adanya perubahan bentuk dan konsistensi tinja dari penderita. Upaya yang dilakukan oleh pemerintah dalam meningkatkan tingkat kesehatan yang optimal diantaranya program pemberantasan penyakit menular, salah satunya adalah program pemberantasan penyakit diare. Puskesmas memiliki sub unit pelayanan seperti posyandu. Salah satu kegiatan pokok dari posyandu yaitu penanggulangan diare. Penelitian ini bersifat deskriptif yaitu suatu metode penelitian yang dilakukan dengan tujuan melihat gambaran fenomena yang terjadi dalam populasi tertentu, dengan pendekatan cross sectional yaitu suatu metode yang merupakan rancangan penelitian dengan melakukan pengukuran atau pengamatan pada saat bersamaan (sekali waktu). Hasil penelitian dilakukan terhadap 38 responden, mayoritas yang terkena diare yaitu 27 responden $(71,1 \%)$. Hasil ini menunjukan tingginya tingkat kejadian diare pada usia $2-4$ tahun di Puskesmas Bandar Kec. Bandar. Faktor lingkungan kurang, terdapat 15 responden (39,4\%)kejadian diare, hasil ini menunjukan ada pengaruh lingkungan terhadap kejadian diare. Fakator perilaku yang buruk terdapat 23 responden $(60,5 \%)$ dengan kejadian diare, menunjukan ada pengaruh perilaku terhadap kejadian diare. Status gizi yang baik dengan ada kejadian diare 17 responden $(44,7 \%)$, hasil ini menunjukkan ada pngaruh status gizi terhadap kejadian diare.
\end{abstract}

Kata Kunci : Diare, Lingkungan, Perilaku, Status Gizi, Anak usia 2-4 tahun

\section{PENDAHULUAN}

Diare pada balita tidak terlepas dari faktor perilaku yang menyebabkan penyebaran kuman enterik terutama yang berhubungan dengan interaksi perilaku ibu dalam mengasuh anak dan faktor lingkungan dimana anak tinggal. Faktor perilaku yang menyebabkan penyebaran kuman enterik dan meningkatkan resiko terjadinya diare yaitu tidak memberikan ASI ekslusif secara penuh pada bulan pertama kehidupan, memberikan susu formula dalam botol bayi, penyimpanan makanan masak pada suhu kamar, menggunakan air minum yang tercemar, tidak mencuci tangan pada saat memasak, makan, atau sebelum menyuapi anak atau sesudah buang air besar dan sesudah membuang tinja anak, dan tidak membuang tinja dengan benar. Faktor lingkungan yaitu sarana air bersih dan pembuangan tinja. Keduanya faktor ini akan berinteraksi dengan perilaku manusia (Nasili dkk, 2011).

Diare dapat disebabkan oleh berbagai infeksi, selain penyebab lain seperti malabsorbsi. Diare merupakan salah satu gejala dari penyakit pada sistem gastrointestinal atau penyakit lain di luar saluran pencernaan. Penyakit diare terutama pada balita perlu mendapatkan tindakan secepatnya karena bisa membawa kematian bila lambat ditangani (Ngatisyah, 2005).
Di negara maju walaupun sudah terjadi perbaikan kesehatan dan ekonomi masyarakat tetapi insiden diare infeksi tetap tinggi dan masih menjadi masalah kesehatan. Di Inggris 1 dari 5 orang menderita diare infeksi setiap tahunnya dan 1 dari 6 orang pasien yang berobat ke praktek umum menderita diare infeksi. Tingginya kejadian diare di negara Barat ini oleh karena foodborne infections(makanan yang terkontaminasi)dan waterborne infections(minuman yangterkontaminasi)(Umar dkk, 2004).

Kementerian Kesehatan (2011), di Indonesia, diare penyebab utama kematian balita, disebabkan tata laksana yang tidak tepat baik di rumah tangga maupun di sarana kesehatan. Untuk menurunkan kematian karena diare perlu tata laksana yang cepat dan tepat. Pada tahun 2010 Kejadian Luar Biasa (KLB) diare terjadi di 11 provinsi dengan jumlah penderita sebanyak 4204 dan meninggal 73 orang dengan CFR tahun 2008 (2,94\%), tahun 2009 (1,74\%), tahun 2010 (1,74\%) (Riri Astika, 2014).

Data Dinas Kesehatan Provinsi Sumatera Utara (2012) menyatakan, jumlah kasus diare yang ditemukan dan ditangani adalah sebanyak $38,67 \%$, dengan IR diare per 1000 penduduk mencapai 16,36\%. Angka ini mengalami penurunan dibandingkan tahun 2011 yaitu 19,35\% dan 2010 yaitu 18,73\% . Pencapaian IR ini jauh di 
bawah target program yaitu 220 per 1.000 penduduk. Kota Medan merupakan daerah endemis penyakit diare. Data dari Dinas Kesehatan Kota Medan mengenai jumlah kunjungan kasus diare yang paling banyak di puskesmas Medan Deli sebanyak 1729 (Riri Astika, 2014).

Dari studi pendahuluan didapatkan data kejadian diare pada balita sejumlah 168 orangbulan Januari sampai Juni tahun 2015. Jumlah balita 687 orang dan jumlah anak 2-4 tahun ada 282 orang dengan balita diare 27 orang. Dari data di atas penelitiingin mengetahui tentang kejadian diare terutama "Faktor-Faktor Yang Berpengaruh Terhadap Kejadian Diare Pada Anak Usia 2-4 Tahun Di Wilayah Kerja Puskesmas Bandar Kecamatan Bandar”.

\section{METODE PENELITIAN}

Penelitian ini bersifat deskriptif yaitu suatu metode penelitian yang dilakukan dengan tujuan melihat gambaran fenomena yang terjadi dalam populasi tertentu, dengan pendekatan cross sectional yaitu suatu metode yang merupakan rancangan penelitian dengan melakukan pengukuran atau pengamatan pada saat bersamaan (sekali waktu).

Populasi penelitian ini adalah seluruh ibu yang mempunyai balita 282 orang tahun 2015 di Kecamatan Bandar berjumlah 282 anak.Tehnik pengambilan sampel adalah dilakukan secara accidental sampling, yaitu pengambilan kasus atau responden yang kebetulan ada atau tersedia di suatu tempat sesuai dengan konteks penelitian. Jenis pengumpulan data adalah jenis data primer yaitu data yang diperoleh secara langsung dari responden (Ibu) dan data sekunder yang diperoleh dari pihak lain, badan institusi yang secara rutin mengumpulkan data. Pengumpulan data menggunakan kuesioner sebanyak 17 soal. Untuk memulai pengumpulan datanya terlebih dahulu memberikan penjelasan kepada responden tentang tujuan penelitian. Bila besedia menjadi responden, dipersilakan untuk mentandatangani surat pesetujuan dan selanjutnya diberikan penjelasan tentang pengisian kuesioner. Jumlah seluruh responden sebanyak 38 responden.

\section{HASIL PENELITIAN}

Faktor-faktor yang berpengaruh terhadap kejadian diare di Puskesmas Bandar Kecamatan Bandar Tahun 2015 dengan jumlah responden 38 orang.

Tabel 1. Distribusi Frekuensi Responden Berdasarkan Kejadian Diare Di Wilayah Kerja Puskesmas Bandar Kecamatan Bandar Tahun 2015

\begin{tabular}{ccc}
\hline Lingkungan & F & \% \\
\hline Ada & 27 & 71,1 \\
Tidak ada & 11 & 28,9 \\
\hline Total & 38 & 100,0 \\
\hline
\end{tabular}

Dari 38 responden diketahui 27 anak $(71,1 \%)$ yang terkena diare sedangkan yang tidak terkena diare 11 responden $(28,9 \%)$ dalam status kejadian diare.

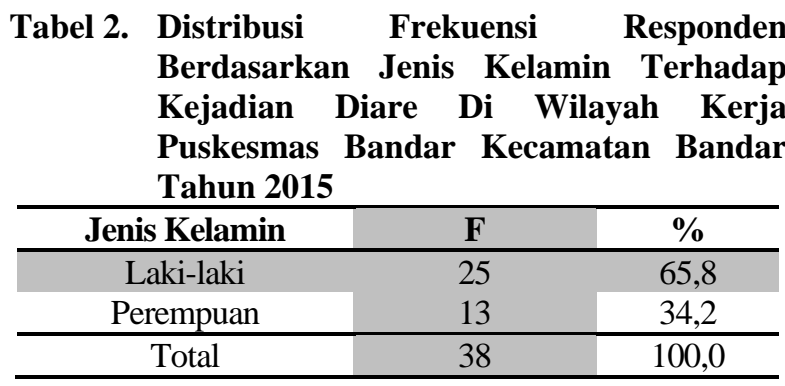

Dari 38 responden diketahui 25 anak $(65,8 \%)$ berjenis kelamin laki-laki dan 13 anak $(34,2 \%)$ berjenis kelamin perempuan yang mengalami diare.

\begin{tabular}{|c|c|c|c|c|c|c|}
\hline & \multicolumn{2}{|c|}{$\begin{array}{l}\text { Distribusi } \\
\text { Berdasarkan }\end{array}$} & \multicolumn{2}{|c|}{$\begin{array}{l}\text { Frekuensi } \\
\text { Lingkungan }\end{array}$} & \multicolumn{2}{|c|}{$\begin{array}{r}\text { Responden } \\
\text { Terhadap }\end{array}$} \\
\hline & \multicolumn{2}{|c|}{$\begin{array}{l}\text { Kejadian D } \\
\text { Puskesmas } \quad \text { E } \\
\text { Tahun 2015 }\end{array}$} & \multicolumn{3}{|c|}{$\begin{array}{l}\text { Diare Di Wilayah } \\
\text { Bandar Kecamatan }\end{array}$} & $\begin{array}{r}\text { Kerja } \\
\text { Bandar }\end{array}$ \\
\hline \multirow[t]{2}{*}{ Lingkungan } & \multicolumn{6}{|c|}{ Kejadian Diare } \\
\hline & Ada & $\%$ & $\begin{array}{l}\text { Tidak } \\
\text { Ada }\end{array}$ & $\%$ & Total & $\%$ \\
\hline Baik & 0 & 0 & 9 & 100 & 9 & 100 \\
\hline Cukup & 12 & 85,7 & 2 & 14,3 & 14 & 100 \\
\hline Kurang & 15 & 100 & 0 & 0 & 15 & 100 \\
\hline Total & 26 & & 12 & & 38 & 100 \\
\hline
\end{tabular}

Dari 38 responden 12 anak $(85,7 \%)$ yang mengalami kejadian diare dalam status lingkungan cukup, 15 anak (100\%) yang mengalami kejadian diare dalam status lingkungan kurang.

\begin{tabular}{|c|c|c|c|c|c|c|}
\hline abel 4. & $\begin{array}{l}\text { Distribus } \\
\text { Berdasa }\end{array}$ & an & $\begin{array}{r}\text { Frekut } \\
\text { Peri }\end{array}$ & $\begin{array}{l}\text { ensi } \\
\text { ilaku }\end{array}$ & & $\begin{array}{l}\text { ponden } \\
\text { rhadap }\end{array}$ \\
\hline & $\begin{array}{l}\text { Kejadian } \\
\text { Puskesm } \\
\text { Tahun 2 }\end{array}$ & $\begin{array}{l}\text { Dia } \\
\text { Ba } \\
5 . \\
\end{array}$ & $\begin{array}{l}\text { re } D \\
\text { ndar }\end{array}$ & $\begin{array}{l}\text { i W } \\
\text { Kecan }\end{array}$ & $\begin{array}{l}\text { ayah } \\
\text { atan }\end{array}$ & $\begin{array}{l}\text { Kerja } \\
\text { Bandar }\end{array}$ \\
\hline Perilaku & & & & an Dia & & \\
\hline & Ada & $\%$ & $\begin{array}{c}\text { Tidak } \\
\text { Ada }\end{array}$ & $\%$ & Total & $\%$ \\
\hline Baik & 4 & 28,6 & 10 & 71,4 & 14 & 100 \\
\hline Buruk & 23 & 95,8 & 1 & 4,2 & 24 & 100 \\
\hline Total & 27 & & | & & 38 & \\
\hline
\end{tabular}

Dari 38 responden diketahui 4 anak $(28,6 \%)$ yang mengalami kejadian diare dalam status perilaku baik, 23 anak $(95,8 \%)$ yang mengalami kejadian diare dalam status perilaku buruk,di wilayah kerja Puskesmas Bandar Kecamatan Bandar. 
Tabel 5. Distribusi Frekuensi Berdasarkan Status Gizi Terhadap Kejadian Diare Di Wilayah Kerja Puskesmas BandarKecamatan Bandar Tahun 2015

\begin{tabular}{lccccccc}
\hline \multicolumn{1}{c}{ Status } & \multicolumn{6}{c}{ Kejadian Diare } \\
\cline { 2 - 7 } & Ada & $\%$ & $\begin{array}{c}\text { Tidak } \\
\text { Ada }\end{array}$ & $\%$ & Total & $\%$ \\
\hline $\begin{array}{l}\text { Gizi Buruk } \\
\text { Gizi Kurang }\end{array}$ & 0 & 0 & 0 & 0 & 0 & 100 \\
Gizi Baik & 10 & 100 & 0 & 0 & 10 & 100 \\
& 17 & 70,8 & 7 & 29,2 & 24 & 100 \\
& 0 & 0 & 4 & 100 & 4 & 100 \\
\hline Gizi Lebih & 27 & & 11 & & 38 \\
\hline Total & & & & & \\
\hline
\end{tabular}

Dari 38 responden diketahui 10 anak (100\%) yang mengalami kejadian diare dalam status gizi kurang, 17 anak $(70,8 \%)$ yang mengalami kejadian diare dalam status gizi baik di wilayah kerja Puskesmas Bandar Kecamatan Bandar.

\section{PEMBAHASAN}

\section{Kejadian Diare}

Penelitian dilakukan terhadap 38 responden tentang Faktor-Faktor Yang Berpengaruh Terhadap Kejadian Diare Pada Anak Usia 2-4 Tahun Di Wilayah Kerja Puskesmas Bandar Kecamatan Bandar mayoritas ada terjadi diare. Hasil penelitian menunjukan dari 38 responden yang terkena diare ada 27 responden $(71,1 \%)$ sedangkan yang tidak ada terkena 11 responden $(28,9 \%)$, hal ini diakibatkan beberapa hal seperti; masyarakat masih menggunakan air sungai untuk keperluan masak dan minum, pembuangan sampah yang ditumpuk ditempat terbuka, kebiasaan anak yang tidak mencuci tangan.

Penyakit diare masih menjadi masalah global dengan derajat kesakitan dan kematian yang tinggi diberbagai negara terutama di negara berkembang, dan juga sebagai salah satu penyebab utama tingginya angka kesakitan dan kematian anak di dunia (Hardi, 2012).Hal ini sejalan dengan hasil penelitian Hamzah B (2012), dari 136 responden menunjukkan balita yang diare sebanyak 61 $(44,9 \%)$, dan yang tidak diare sebanyak 75 balita $(55,1 \%)$. Hal ini menunujukan tingginya kejadian diare.

\section{Lingkungan}

Hasil penelitian menunjukan 38 responden dengan lingkungan yang baik mayoritas tidak ada kejadian diare 9 responden $(23,7 \%)$, lingkungan yang cukup mayoritas ada kejadian diare 12responden (31,6\%), dan lingkungan yang kurang mayoritas ada kejadian diare 15 responden $(39,4 \%)$. Hal ini terjadi karena pengelolaan sampah ditumpuk di halam rumah, keadaan air di rumah masih ada yang berwarna dan berbau, pengelolaan air limbah masih ada yang menimbulkan genangan, dan jarak septic tank dengan sumber air bersih masih ada yang kurang dari 10 meter.Faktor lingkungan yang paling dominan yaitu sarana penyediaan air bersih dan pembuangan tinja, kedua faktor ini akan berinteraksi bersama dengan perilaku manusia. Apabila faktor lingkungan tidak sehat karena tercemar kuman diare serta berakumulasi dengan perilaku manusia yang tidak sehat pula, maka penularan diare dengan mudah dapat terjadi (Evayanti, 2014).Hal ini sejalan dengan hasil penelitian Hardi (2012), menunjukkan bahwa dari 174 responden yang memiliki sanitasi lingkungan yang cukup, sebanyak 100 batita $(57,47 \%)$ tidak terkena diare, dan 74 batita $(42,53 \%)$ terkena diare. Dari 46 responden yang faktor sanitasi lingkungannya kurang, sebanyak 17 batita $(36,96 \%)$ tidak terkena diare dan selebihnya terkena diare. Maka disimpulkan lingkungan berpengaruh dalam kejadian diare.

\section{Perilaku}

Hasil penelitian menunjukan perilaku yang baik mayoritas tidak ada kejadian diare 10 responden $(26,3 \%)$, dan perilaku yang buruk mayoritas ada kejadian diare 23 responden $(60,5 \%)$,hal ini terjadi karena masih ada kebiasaan tidak mencuci tangan sebelum dan sesudah makan atau melakukan aktifitas seperti bermain, memegang uang, menyuapi anak, masih ada anak yang sering jajan sembarangan, tidak memakai alas kaki saat bermain.Menurut Wahit Iqbal personal higiene atau kebersihan diri adalah upaya seseorang dalam memelihara kebersihan dan kesehatan dirinya untuk memperoleh kesejahteraan fisik dan psikologis. Menurut Muhajirin, Kebiasaan tidak mencuci tangan dengan sabun sesudah buang air besar merupakan kebiasaan yang dapat membahayakan bayi terutama ketika ibu memasak makanan atau menyuapi balita makan(Hardi, 2012), sejalan hasil penelitian Hardi (2012), yang menunjukan dari 217 resopnden yang nilai hygiene perorangannya kurang, sebanyak 115 batita $(53,18 \%)$ tidak terkena diare, dan sisanya batita sebanyak 102 orang $(46,82 \%)$ terkena diare. Hal ini menunjukan perilaku berpengaruh terhadap kejadian diare.

\section{Status Gizi}

Status gizi kurang mayoritas ada kejadian diare 10 responden $(26,3 \%)$, status gizi yang baik mayoritas ada kejadian diare 17 responden $(44,7 \%)$ dan status gizi yang lebih baik mayoritas tidak ada kejadian diare 4 responden $(10,6 \%)$. Hal ini terjadi karena, kurang memperhatikan gizi anak seperti, anak jarang makan ikan, anak jarang makan sayur, anak jarang makan buah dan lebih suka makan jajanan yang dibeli di pinggir jalan. Sejalan penelitian Fahmi (2013), sebanyak 58\% dari balita yang memiliki gizi baik menderita diare, dan $42 \%$ dari balita tersebut tidak diare. Balita dengan gizi tidak baik sebanyak 29 balitadimana sebanyak 38\% menderita diare, dan $62 \%$ tidak diare. Pada balita denganstatus gizi tidak baik, angka kejadian diare sebesar 36\%, angka ini lebihkecil dari angka tidak diare sebanyak $64 \%$, hal ini secara perhitungan didapatkandata yang tidak bermakna, dimana pada status gizi tidak baik angka kejadian diarelebih rendah daripada tidak diare, dan juga pada kelompok status gizi baik, angkakejadian diare lebih tinggi daripada tidak diare. 


\section{SIMPULAN}

1. Hasil penelitian dilakukan terhadap 38 responden yang terkena diare ada diare ada 27 responden $(71,1 \%)$ sedangkan yang tidak ada terkena 11 responden $(28,9 \%)$.Hasil ini menunjukan tingginya tingkatkejadian diarepada usia 2-4 tahun di Puskesmas Bandar Kec. Bandar.

2. Hasil penelitian menunjukan 38 responden dengan lingkungan yang baik mayoritas tidak ada kejadian diare 9 responden $(23,7 \%)$, lingkungan yang cukup mayoritas ada kejadian diare 12 responden $(31,6 \%)$, dan lingkungan yang kurang mayoritas ada kejadian diare 15 responden $(39,4 \%)$.Hasil ini menunjukan ada pengaruh lingkungan terhadap kejadian diare.

3. Hasil penelitian dilakukan terhadap 38 responden menunjukan perilaku yang baik mayoritas tidak ada kejadian diare 10 responden $(26,3 \%)$, dan perilaku yang buruk mayoritas ada kejadian diare 23 responden (60,5\%).Hasil ini menunjukan ada pengaruh perilaku terhadap kejadian diare.

4. Hasil penelitian dilakukan terhadap 38 responden status gizi yang kurang mayoritas ada kejadian diare 10 responden $(26,3 \%)$, status gizi yang baik mayoritas ada kejadian diare 17 responden $(44,7 \%)$ dan status gizi yang lebih baik mayoritas tidak ada kejadian diare 4 responden $(10,6 \%)$.

\section{SARAN}

Kepada ibu-ibu yang memiliki balita berupaya menciptakan lingkungan yang baik seperti menjaga kebersihan di dalam maupun diluar rumah, berperilaku baik dengan mengajarkan anak mencuci tangan, dan menjaga kesehatan anak seperti makanan yang dikonsumsi anak.Bagi petugas kesehatan di Puskesmas Bandar untuk lebih meningkatkan kegiatan di Puskesmas seperti penyuluhan tentang penyakit salah satunya diare.

\section{DAFTAR PUSTAKA}

Amaliah, Siti. 2010. Hubungan Sanitasi Lingkungan Dan faktor Budaya Dengan Kejadian Diare Pada Anak Balita Di Desa Toriyo Kecamatan Bendosari Kabupaten Sukoharjo.(http://jurnal.unimus.ac.id)

Atikah \& Eni. 2014. Perilaku Hidup Bersih \& Sehat (PHBS).Yogyakarta. Nuha Medika.
Cecily \& Linda. 2009. Keperawatan Pediatri.Edisi 5. Jakarta. EGC.

Fauziah, 2013. Hubungan Faktor Individu Dan Karateristik Sanitasi Air Dengan Kejadian Diare Pada Balita Umur 10-59 Bulan.Bekasi. Universitas islam Negeri Syarif Hidayatullah Jakarta : Jurnal.

Indriani, Riri, Astika. 2014. Analisis Pelaksanaan Program Diare Di Puskesmas Medan Deli Kecamatan Medan Deli.Medan : Jurnal

Kasaluhe, Meityn, D, dkk. 2013. Faktor-Faktor Yang Berhubungan Dengan Kejadian Diare Pada Balita Di Wilayah Kerja Puskesmas Tahuna Timur Kabupaten Kepulauan Sangihe. Manado : Jurnal

Malikah, Lina, dkk. 2012. Gambaran Pengetahuan Dan Sikap Ibu Dalam Pencegahan Dan Penanggulangan Secara dini Kejadian Diare Pada balita Di Desa Hegarmanah Jatinagor.(malik_ahh@yahoo.co.id)

Nasili, dkk. 2011. Perilaku Pencegahan Diare Anak Balita di Wilayah Bantaran Kali Kelurahan Bataraguru Kecamatan Wolio Kota Bau-Bau.Sulawesi Utara : Jurnal.

Ngatisyah. 2005. Perawatan Anak Sakit. Edisi 2. Jakarta. EGC.

Notoatmodjo, Soekidjo. 2011. Kesehatan Masyarakat Ilmu\&Seni.Jakarta. Rineka Cipta. Semarang. Universitas Diponegoro : Jurnal.

Wawan \& Dewi. 2011.Teori \& Pengukuran Pengetahuan, Sikap, dan Perilaku Manusia.Yogyakarta. Mulia Medika

Zein, Umar, dkk. 2004. Diare Akut Disebabkan Bakteri. Sumatra Utara : Jurnal. 